\author{
Marta KUŁAGA \\ Leance \\ marta.kulaga@leance.org \\ Magdalena TRZCIONKA \\ Uniwersytet Jagielloński \\ magdalena.trzcionka@uj.edu.pl
}

\title{
GRANICE WYOBRAŻONE I RZECZYWISTE - EWOLUCJA I TRANSGRESJA
}

\author{
ZMIANA PARADYGMATU FUNKCJONOWANIA ORGANIZACJI \\ NA PRZYKŁADZIE KRAKOWSKIEJ ORGANIZACJI LEANCE
}

ABSTRACT Imaginary and Real Boundaries - Evolution and Transgression. The Change of an Organizational Model's Paradigm Based on the Example of Leance a Teal Organization from Krakow

The article discusses issues related to the real and imaginary limitations of the functioning of teal organizations. Both categories of boundaries are thought constructs, and the proposed distinction is determined by the process of transgression. A crossed barrier becomes an imaginary boundary, the one to be defeated remains real. The analysis of boundaries and transgression was based on the theory of psychotransgressionism by Józef Kozielecki, and the case study concerned the Krakow teal organization - Leance. The primary focus was on the area of communication, relations and interactions.

Keywords: teal organization, transgression, organizational change, nonviolent communication by Marshall Rosenberg

Słowa kluczowe: turkusowa organizacja, turkusowy model organizacyjny, zmiana organizacyjna, transgresja, Porozumienie bez przemocy 
Zycie, wypetnione mozotem przekraczania granic materialnych,
spotecznych i symbolicznych, staje się czesto życiem sensownym.
Józef Kozielecki

Granice? Nigdy żadnej nie widziatem, ale styszatem, że istnieją w umystach niektórych ludzi.

Thor Heyerdahl

Stowa moga być oknami lub murami.

Ruth Bebermeyer

\section{WPROWADZENIE}

Ken Wilber w Niepodzielonych napisal, że świat ludzi funkcjonuje w obrębie granic. Gdy na rzeczywistość nabudowana zostanie jakaś granica, granica ta rodzi dwa pozorne przeciwieństwa ${ }^{1}$ : TU, gdzie aktualnie się znajdujemy, i TAM, gdzie nas nie ma. Znaczenie nadane przez nas czasoprzestrzeni TU i TAM rodzi potrzeby, a wraz z nimi rodzaj napięcia, dyskomfortu, niekiedy cierpienia związanego $\mathrm{z}$ wymogiem ich zaspokojenia. Cierpienie - pisze Wilber - jest zatem pierwotnym impulsem ku uznaniu fatszywości granic. Jeżeli się je dobrze zrozumie, posiada dziatanie wyzwalające, ponieważ popych a ku przekroczeniu granic ${ }^{2}$. W artykule podjęto próbę analizy powstania i ewolucji turkusowego modelu organizacyjnego pracy. Ewolucja modeli organizacyjnych następuje na ścieżce transgresji dotychczasowych ram działalności człowieka i organizacji, a wyjście poza schemat zmienia charakter przekroczonych granic. Tematyka ewolucji i transgresji turkusowych organizacji jest niezwykle interesująca z kilku względów.

Po pierwsze, turkusowy model organizacyjny wpisuje się w popularny obecnie nurt „zwinnych” rozwiązań (agile). Agile początkowo odnosił się do metod programowania informatycznego, ale zmienił perspektywę postrzegania pracy ludzkiej w kilku kluczowych aspektach. Mianowicie przekierował uwagę z procesów i narzędzi na ludzi i ich interakcje, podstawową wartość pracy odbijał w działającym produkcie, a nie w przygotowaniu szczegółowej dokumentacji projektowej i wykonawczej, współpracę z klientem cenił wyżej niż czas spędzony na negocjowaniu umów i przyznawał wyższy priorytet reagowaniu na zmiany niż realizacji ustalonego planu ${ }^{3}$. Na bazie tych założeń i na podstawie konkretnych turkusowych praktyk organizacyjnych powstaje coraz więcej firm, także na rynku polskim. Przeniesieniem niektórych turkusowych rozwiązań zainteresowany jest również sektor organizacji pozarządowych oraz agendy administracji publicznej.

$1 \quad$ K. Wilber, Niepodzielone. Wschodnie i zachodnie teorie rozwoju osobowości, przeł. T. Bieroń, Poznań 2014, s. 110.

2 Tamże, s. 123.

3 Zob. Manifesto for Agile Software Development, [online] http://agilemanifesto.org/, 21 II 2018. 
Po drugie, reaktywność agile’u i ewolucyjny charakter turkusowego modelu stawiają mocny akcent na problematykę łamania schematów, nieszablonowego myślenia i działania oraz przekraczania dotychczasowych granic. Założenia turkusowego modelu zupełnie odbiegają od współczesnych rozwiązań organizacyjnych. Wdrożenie tego typu rozwiązań wymagać może nie tyle zmiany, co transgresji na inny poziom rozumienia siebie, współpracy z innymi ludźmi, rzeczywistości funkcjonowania na rynku, na którym działają tradycyjnie zarządzane podmioty. Transgresja odbywać się może w kilku wymiarach jednocześnie, jest stymulowana i hamowana przez różnorodne czynniki wewnętrzne i zewnętrzne. Proces przekraczania granic zmienia ich charakter $\mathrm{z}$ rzeczywistych na wyobrażone, rozszerzając perspektywę patrzenia i paletę dostępnych możliwości.

Po trzecie, podstawowym narzędziem transgresji, tak w wymiarze osobistym, jak i na poziomie organizacji i społeczeństwa jest komunikacja. Przykład funkcjonowania i ewolucji turkusowych organizacji dowodzi, że szanse na pokonanie przeszkód i rozwiązanie problemów zwiększa głębszy kontakt między ludźmi oraz wzajemne zrozumienie i uznanie potrzeb. W zakreślonych wyżej ramach sformułowano następujące pytania badawcze:

- Jak należałoby zdefiniować pojęcie transgresji? Jakie są jej źródła i rodzaje?

- Co należy rozumieć pod pojęciem granicy rzeczywistej i wyobrażonej?

- W jaki sposób kategoria transgresji znajduje zastosowanie w analizie i wyjaśnianiu ewolucji modeli organizacji pracy ludzkiej?

- Jakie sągranice rzeczywiste i wyobrażone turkusowego modelu organizacyjnego?

- W jaki sposób konstruktywna komunikacja staje się narzędziem transgresji na poziomie indywidualnym, organizacji i poziomie społecznym?

Odpowiedzi na nie zawierają kolejne podrozdziały pracy.

W pierwszej części podjęto próbę zdefiniowania pojęcia granicy i transgresji. Dokonano tego na podstawie teorii psychotransgresjonizmu Józefa Kozieleckiego. W zaproponowanych przez niego ramach teoretycznych zbudowano definicję granicy wyobrażonej i rzeczywistej, którą w dalszej części pracy odniesiono do praktyki funkcjonowania turkusowych organizacji. W drugiej części zaprezentowano ewolucję modeli organizacji pracy ludzkiej, jej główne przełomy oraz wypracowane na każdym etapie praktyki. W części trzeciej podjęto próbę analizy procesu transgresji w turkusowych organizacjach, na podstawie koncepcji psychotransgresjonizmu Józefa Kozieleckiego, integrując trzy postmodernistyczne nurty badań nad zmianą organizacyjną: nurt dynamiki grupowej, ewolucyjny oraz systemowy. W tym celu przeprowadzono wywiady z reprezentantami pięciu Turkusowych Organizacji działających na terenie Polski, ich pracownikami i właścicielamí. W części czwartej, dotyczącej porozumienia bez przemocy (nonviolent communication - NVC, perspektywy komunikacji zorientowanej na potrzeby), przedstawiono rolę komunikacji międzyludzkiej, zrozumienia siebie, swoich

4 W tym miejscu autorki chciały wyrazić słowa wdzięczności pracownikom i właścicielom firm: (w kolejności alfabetycznej) Artifex Mundi, Ingrado, Leance, Mentax oraz Turkus Info, którzy wzięli udział w badaniu. W nadziei autorek ich wkład przyczyni się do powstania zestawu dobrych praktyk, które odmienią oblicze współczesnego rynku pracy. 
motywów, wartości i pragnień, zrozumienia innych osób i ich intencji oraz przyczynienia się do transgresji organizacyjnej. W części piątej zaprezentowano analizę przypadku krakowskiej organizacji Leance i historii jej powstania w aspekcie procesu komunikacji. Studium przypadku ukazuje praktykę zastosowania NVC w rzeczywistości organizacyjnej i biznesowej.

Przekraczanie granic w kontekście rozwoju organizacji tworzy zupełnie nowe jakości, do których jedni są przekonani, a inni czują wobec nich głęboki sceptycyzm. Bez względu na tę odmienność postaw, potrzeba humanizacji środowiska pracy jest już na tyle wyraźnie artykułowana, tak przez pracowników, jak i pracodawców, że możliwości oferowane przez turkusowy model organizacyjny nie mogą być nadal ignorowane. Uzasadnione staje się więc stworzenie zbioru dobrych praktyk, które stanowić mogą cenne instrumentarium w procesie implementacji turkusowych rozwiązań.

\section{METODYKA BADAŃ I PRZEBIEG PROCESU BADAWCZEGO}

W procesie powstawania niniejszego opracowania szczególnym wyzwaniem był interdyscyplinarny charakter problematyki, który wymagał poszukiwań w obszarze trzech dziedzin: nauk o zarządzaniu (turkusowy model organizacji pracy), psychologii (psychotransgresjonizm J. Kozieleckiego) oraz nauk o poznaniu i komunikacji (porozumienie bez przemocy Marshalla Rosenberga). Badanie zostało poprzedzone przeglądem literatury przedmiotu. Analiza granic wyobrażonych i rzeczywistych turkusowego modelu organizacyjnego została wsparta wywiadami z przedstawicielami turkusowych przedsiębiorstw działających w Polsce. Wywiady te nie spełniają jednak rygoru metodologicznego, ponieważ w zamiarze autorek miały być jedynie materiałem uzupełniającym, przykładem z życia wziętym, potwierdzającym tezy Józefa Kozieleckiego. Główną metodą badawczą przyjętą przez autorki była analiza przypadku. Przesłanką wyboru metody był przede wszystkim fakt, iż rozwój wiedzy na temat granic turkusowego modelu organizacyjnego jest we wstępnej fazie. Literatura naukowa prezentująca jego założenia nie jest zasobna, chociaż powstaje coraz więcej firm implementujących w różnym zakresie turkusowe rozwiązania. Przyglądanie się granicom modelu organizacji pracy przez pryzmat psychotransgresjonizmu wydaje się autorkom szczególnie interesujące. Nowatorskie ujęcie tematu przekraczania granic na poziomie osobistym i ogólnoludzkim w myśli Kozieleckiego pozostaje wciąż aktualne w dobie zmienności i złożoności otaczającej nas rzeczywistości. Psychotransgresjonizm, zdaniem autorek, jest wart ponownego odkrycia i pogłębionych badań.

Empatyczna komunikacja w duchu NVC z założenia kwestionuje i poddaje weryfikacji osąd świata i człowieka. Interpretacja rzeczywistości, w tym działań innych ludzi, staje się kodem dostępu do własnych potrzeb, wartości i motywacji. Człowiek ponosi odpowiedzialność za zaspokajanie własnych potrzeb i za dobór strategii realizacji tego celu. NVC demaskuje niekiedy nieuświadomiony wymiar relacji opartych na potrzebach, warunkujący proces podejmowania decyzji. Po raz kolejny uwidacznia to istnienie silnej zależności pomiędzy zmianą w wymiarze osobistym i strukturalnym 
w organizacji. W tym kontekście każda interakcja staje się okazją do transgresji zastanych struktur i zmian w interpretacji rzeczywistości. Rozwój wiedzy o NVC jako „paliwie" transgresji jest we wstępnej fazie. Dotychczas nie przeprowadzono badań na temat wpływu konstruktywnej komunikacji na usprawnienie procesu tworzenia turkusowej organizacji lub transformacji istniejącego modelu organizacyjnego.

Kolejny argument uzasadniający wybór metody studium przypadku stanowi potrzeba rozpoznania zjawiska w rzeczywistych warunkach. Analiza granic rzeczywistych i wyobrażonych oraz roli, jaką pełni komunikacja w transgresji, została przedstawiona na podstawie doświadczeń krakowskiej turkusowej organizacji - Leance, której założycielką jest jedna z autorek. Dzięki temu studium wyszło poza ramy badania typu desk-research, a badanie zyskało tym samym głębszy wgląd w praktykę funkcjonowania turkusowej organizacji. Zgromadzone dane poddano analizie i na ich podstawie sformułowano uogólnienia. Następnie skonfrontowano je z dostępną literaturą i uzupełniono materiał empiryczny o dodatkowe dane (uzupełniające wywiady z turkusowymi firmami). Badanie zamknęło się sformułowaniem uogólnień orzekających o cechach, relacjach i wzorcach dynamiki zdarzeń.

Zamiarem autorek nie jest tworzenie teorii. Tekst ma stanowić rodzaj inspiracji do rozszerzenia percepcji i świadomości ograniczających jednostkę, sposobów postrzegania organizacji i możliwości oraz uwarunkowań transformacji organizacji.

\section{GRANICA I TRANSGRESJA}

Struktura modeli organizacyjnych wspólnot ludzkich jest manifestacją natury człowieka jako jednostki intencjonalnej, która stawia przed sobą cele będące nośnikiem potencjalnych wartości i znaczeń. Model organizacyjny wyznacza dla działalności człowieka pewne ramy, a sam proces wyłaniania się i ewolucji formuł współdziałania polega na wychodzeniu poza dotychczasowe schematy i procedury funkcjonowania. Rozwój modeli organizacyjnych pracy ludzkiej nie odbywa się liniowo, lecz spiralnie, i jest sekwencją zmian o charakterze ewolucyjnym i inwolucyjnym ${ }^{5}$. Stan rozwoju jest wynikiem postępu i cofania się w różnym tempie i zakresie. Każdy kolejny model przekracza i zawiera jakości wszystkich poprzednich, które funkcjonują w nim jako dostępne, możliwe do uruchomienia zasoby ${ }^{6}$. W tej perspektywie badanie transgresji jako ścieżki rozwoju nie może opierać się na kategorii granicy rozumianej jako przeszkoda lub bariera, ale linii, która wyznacza zakres dotychczasowych osiągnięć człowieka, ramy, w której człowiek działa ${ }^{7}$. Granice mogą mieć charakter materialny, społeczny, symboliczny oraz

Zob. K. Wilber, Eksplozja świadomości, przeł. K. Przechrzta, E. Kluz, Kraków 1997; tenże, The Atman Project: A Transpersonal View of Human Development, Wheaton IL 1996.

6 D.E. Beck, Ch.C. Cowan, Spiral Dynamics: Mastering Values, Leadership, and Change: Exploring the New Science of Memetics, Malden 2011, s. 48-114.

Definicję granicy jako rejonu działania człowieka zaczerpnięto z pracy twórcy psychologii topologicznej K. Lewina [w:] J. Kozielecki, Psychotransgresjonizm. Nowy kierunek w psychologii, Warszawa 2001, s. 37. 
osobisty $^{8}$. Przekraczanie granic wprowadza zmianę, przekształca rzeczywistość poprzez tworzenie nowych form i struktur?.

Józef Kozielecki, tworząc nowy kierunek psychologii - psychotransgresjonizm wskazywał, że aktywność poznawcza i praktyczna, akty myślenia i czyny człowieka mogą być uporządkowane wedle dwóch rodzajów działań: ochronnych, pozwalających zdobyć wartości niezbędne do utrzymania egzystencji i zachowania równowagi organizmu, oraz transgresyjnych, w ramach których człowiek przełamuje granice, by zdobyć lub stworzyć nowe wartości ${ }^{10}$. Nie każda zmiana to transgresja. Ken Wilber wprowadza rozróżnienie między zmianą (translacją), która odbywa się w ramach jednego poziomu rozwoju (jednego modelu organizacyjnego), a przemianą (transformacją), która dokonywana jest $\mathrm{w}$ wyniku transgresji $\mathrm{i}^{11}$. Istnienie współczesnych organizacji definiowane jest w kategoriach zmiany adaptacyjnej i rozwoju, które są warunkiem koniecznym ich istnienia. Innymi słowy, zdolność przetrwania organizacji oceniana jest na podstawie możliwości rozwojowych, co lokuje optykę analizy na działania transgresyjne. Kozielecki definiuje transgresję jako proces myślenia i działania praktycznego, ukierunkowanego na przekroczenie granic przestrzeni i czasu, w których człowiek był dotychczas aktywny ${ }^{12}$. W tym miejscu należy zaznaczyć, że cele czynności transgresyjnych takich jak poszukiwanie, konstruowanie, reformowanie lub odkrywanie często są zmienne, rozmyte i formułowane z pewnym opóźnieniem, nie pełnią czołowej roli, ustępując miejsca dumie i satysfakcji wynikającej z zaangażowania jednostki. Kozielecki twierdzi, że to właśnie istnienie granicy wzmacnia motywację i wywołuje pozytywne emocje, ponieważ za nią znajdują się zjawiska niepewne, nieznane, nieokreślone, ryzykowne i nieoczekiwane. Granica stanowi wyzwanie. Transgresje, z pewnymi wyjątkami, nie są konieczne, ale możliwe. W przeciwieństwie do działań ochronnych, które z reguły są planowane i wykonywane $\mathrm{z}$ wykorzystaniem wiedzy proceduralnej, transgresje cechuje spontaniczność. Reguły gry nie są z góry określone, ale zmieniają się w czasie w zależności od zaistniałych warunków.

Kozielecki wyróżnia transgresje typu P (psychologiczne, prywatne), które polegają na przekraczaniu swoich osobistych granic i dotyczą jednostek i małych grup społecznych. Obok nich występują transgresje typu $\mathrm{H}$ (historyczne), w procesie których sprawcy przekraczają granice materialne i symboliczne oraz docierają w obszary dotychczas nieujawnione. Transgresje mogą mieć charakter ekspansywny i twórczy. Transgresje ekspansywne polegają na zwiększeniu zasięgu kontroli i wpływu, transgresje twórcze rozszerzają granice poznania, otwierając nowe przestrzenie ${ }^{13}$. Szczególnym rodzajem transgresji,

8 Granica fizyczna wykrawa $z$ otoczenia terytorium prywatne jednostki; granica spoteczna wyznaczana jest m.in. przez nakazy publiczne, pozycje spoteczna, zakres posiadanej wtadzy; granica intelektualna (symboliczna) staje się zakres posiadanej wiedzy o świecie $i$ samym sobie; granica osobista odnosi sie do świata wewnętrznego jednostki i dotyczy stopnia rozwoju osobowości lub osiagnię́ indywidulanych. J. Kozielecki, Psychotransgresjonizm..., s. 37; tenże, Transgresja i kultura, Warszawa 1997, s. 45.

9 Tenże, Transgresja i kultura..., s. 49-58.

10 Tenże, Psychotransgresjonizm..., s. 33-36.

$11 \quad$ K. Wilber, Eksplozja świadomości..., s. 247.

12 J. Kozielecki, Koncepcja transgresyjna cztowieka. Analiza psychologiczna, Warszawa 1987, s. 44.

13 Tenże, Transgresja i kultura..., s. 42-43. 
mieszczącym się w zbiorze cech konstytuujących turkusową organizację, jest zjawisko emergencji, które polega na spontanicznym tworzeniu nowych jakościowo wartości, wzbogacających strukturę systemu o nowe elementy. Kozielecki stwierdza, że ujawnienie się nowych cech systemu jest możliwe dzięki jego samoorganizacji i wewnętrznej dynamice. Emergencja skategoryzowana jest jako transgresja osobliwa, ponieważ zachodzi ona spontanicznie, jej cele są nieznane i nie jest kontrolowana przez świadomośćc ${ }^{14}$.

Kozielecki w swoich rozważaniach dotyka problemu granicy transgresji, rozważając, czy granice są przekraczalne i w jakich warunkach. Wyróżnia on granice przekraczalne w danym okresie historycznym i w danych warunkach kulturowych oraz granice nieprzekraczalne na danym etapie rozwoju jednostki i społeczeństwa. Odżegnuje się od kategorycznych sądów o istnieniu granic absolutnych, czyli limitów, których nigdy nie uda się przełamać. Podkreśla jednak dobitnie, że brzegi ludzkich możliwości są otwarte i ponieważ ciagle się je rozszerza, wiele projektów niewykonalnych w przesztości obecnie powszechnie się realizuje ${ }^{15}$. Jak w takim razie określić, czym są granice wyobrażone i rzeczywiste?

Człowiek lub grupa ludzi (organizacja) określa cel, który wykracza poza aktualne ramy działania. Podmiot chciałby opuścić obszar subiektywnie rzeczywistego TU, by znaleźć się w wyobrażonym TAM (rysunek 1).

Rysunek 1. Transgresja jako proces transformacji granic rzeczywistych w wyobrażone

wyobrażone TAM

TRANSGRESJA.
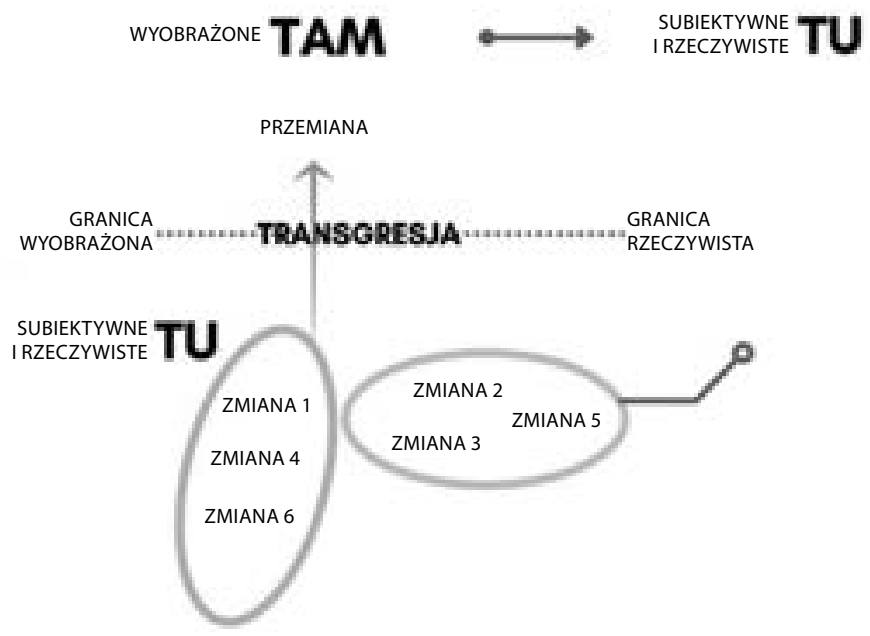

Źródło: opracowanie własne

14 Tenże, Psychotransgresjonizm..., s. 43-45.

15 Tenże, Transgresja i kultura..., s. 39-46. 
Stan docelowy - wyobrażone TAM - istnieje w zamyśle, w wyobraźni, w planach podmiotu. Granica wyznaczająca dotychczasowy obszar działania jest subiektywnie rzeczywista, ponieważ gdyby jej nie było, to podmiot nie byłby oddzielony od wyobrażonego TAM. Dlatego próbuje on ustalić, jakich zmian powinien dokonać, aby osiągnąć założony cel. Jeśli adekwatnie zaplanuje rodzaj zmian i je zrealizuje, dokona transgresji i doświadczy przemiany, lokując się w wyobrażonym TAM. Jeśli zmiany, których dokona, nie doprowadzą do zrealizowania celu, podmiot pozostanie w obszarze dotychczasowych granic, które potwierdzi subiektywnie jako rzeczywiste. W takim razie sama wiara podmiotu, że dokonanie koniecznych zmian wplynie na osiągnięcie celu, podaje w wątpliwość rzeczywisty charakter granicy. Jeśli podjęte działania zakończą się sukcesem, dotychczasowe granice okazują się wyobrażone. Z kolei jeśli w wyniku podjętych działań podmiotowi nie uda się zrealizować założonego celu, granice pozostają rzeczywiste. Proces transgresji przekształca granice rzeczywiste w granice wyobrażone, a stymulatorem transgresji jest wiara w to, że podjęte działania skutkować mogą osiągnięciem stanu docelowego. Po dokonaniu przemiany dotychczas wyobrażone TAM staje się subiektywnie rzeczywistym TU i proces ustalania kolejnych celów może rozpocząć się na nowo. W takim razie można założyć, że granice istnieją w umyśle podmiotu, są konstruowane. Ustalanie obszaru działania, obieranie nowego celu, komponowanie zmian, których dokonanie jest konieczne w ramach transgresji, jest procesem konceptualnym. W jego ramach granice są rzeczywiste. Podjęte działanie jest swoistym sprawdzeniem autentyczności statusu granicy. Proces transgresji rozciągnięty w czasie odsłania nowe aspekty sytuacji, zmienia niekiedy jej kontekst, a samo przekraczanie granic determinowane być może innymi czynnikami, które pojawiają się w wyniku sprzężenia zwrotnego. Granica w analizie dynamicznej staje się kategorią płynną, a proces transgresji nabiera nowych znaczeń i przynosi odmienne wartości.

\section{DZIAŁANIA TRANSGRESYJNE W OBSZARZE MODELI ORGANIZACYJNYCH PRACY LUDZKIEJ}

Płynność statusu granicy, wynikającą z jego konceptualnego charakteru, pogłębia dodatkowo fakt, iż na działalność transgresyjną wpływają nie tyle zasoby osobowe czy kapitał psychiczny jednostki lub grupy, ale okoliczności. Zdaniem J. Kozieleckiego źródłem transgresji historycznych jest tzw. duch czasu (Zeitgeist), czyli zespót sprzyjajacych okoliczności ekonomicznych, spotecznych, kulturowych i politycznych, które powoduja, iz dane odkrycie, wynalazek czy reforma ustrojowa sq "na końcu jezyka” i muszq wcześniej czy później się zdarzyć. I zachodza z żelazną koniecznością ${ }^{16}$. Każda kultura ma swój paradygmat, który określa, co jest przechowywane w pamięci, a co ulega zapomnieniu.

Podobne konstatacje na temat rozwoju ludzkiej cywilizacji w kontekście ewolucji modeli organizacyjnych pracy przedstawia Frederic Laloux w swej książce zatytułowanej Pracować inaczej. Zdaniem Laloux człowiek organizuje swoją działalność

16 Tamże, s. 173. 
zgodnie z panującym w danym okresie światopoglądem i stanem świadomości. Laloux analizuje kolejne etapy rozwoju świadomości przez pryzmat światopoglądu, kluczowych potrzeb, rozwoju poznawczego i rozwoju moralnego ${ }^{17}$. Każdemu etapowi przyporządkowuje on nazwę oraz kolor, inspirując się przede wszystkim kolorowym kodem teorii integralnej Kena Wilbera oraz metaanaliz Jenny Wade ${ }^{18}$. Każdej kolorowej organizacji Laloux przypisuje osobną metaforę ułatwiającą zobrazowanie podstawowych założeń paradygmatu, w który wpisuje się model organizacyjny. I tak: czerwona organizacja przyjmuje obraz watahy wilków lub mafii, bursztynowa organizacja armii lub Kościoła katolickiego, pomarańczowa organizacja maszyny, a zielona przedstawiona została jako rodzina. Turkusowej organizacji Laloux przypisuje metaforę żywego organizmu.

Rozwój paradygmatów odbywa się w dwóch etapach. Punktem granicznym transgresji jest moment przejścia z poziomu pluralistycznej Zieleni do Turkusu. Granica rozszerza swoją definicję w myśl koncepcji transgresyjności Kozieleckiego i staje się ramą dotychczasowej działalności organizacji. Wyjście poza w paradygmacie turkusowym nie polega już na pokonaniu przeszkód. Przedstawiciele wszystkich omówionych wyżej paradygmatów uważają swój światopogląd za jedyny właściwy, naprawiając błędy i niedopatrzenia poprzedników. Transgresja na tym poziomie polega na zauważeniu i zaakceptowaniu ciągłej ewolucji ludzkiej świadomości oraz przyjęciu poglądu, że nabiera ona rozpędu w kierunku coraz bardziej złożonych i udoskonalonych sposobów radzenia sobie ze światem. Poczucie sprawczości i kontroli nad otoczeniem zamazuje się, a człowiek zaczyna świadomie wygaszać identyfikację z własnym ego. To oddzielenie pozwala na uwolnienie się od lęków związanych z życiem, przyszłością i granicami swoich możliwości. Skutkuje ono również zmniejszeniem potrzeby kontrolowania świata zewnętrznego: ludzi i zdarzeń. Ludzie zawierzają swojej intuicji w procesie podejmowania decyzji w poczuciu uczciwości i własnej autentyczności. Turkusowa perspektywa operuje w głębszym poczuciu celu, tkwiącym w potrzebie życia w pełni i realizowania swojego powołania. Dochodzenie do pełni jest procesem cechującym się złożonością i zmiennością. Opiera się on na integralnym podejściu do poznania. Turkus czerpie ze wszystkich dostępnych teorii i źródeł wiedzy, tak analitycznych, jak i bazujących na emocjach i intuicjach. Przełomem poznawczym turkusowego paradygmatu jest przekroczenie dualizmów poprzez myślenie w kategoriach „zarówno jedno, jak i drugie", a tym samym przejście z paradygmatu mechanistyczno-deterministycznego

17 Laloux, opierając się przede wszystkim na pracach dotyczących rozwoju ludzkiego takich autorów jak Abraham Maslow, Clare W. Graves, Don E. Beck i Christopher C. Cowan oraz Ken Wilber, przekonuje, że przejście na nowy poziom świadomości wprowadzało zmiany w wielu obszarach życia, tak w społeczeństwie (przejście od klanów przez plemiona, imperia do państw narodowościowych), jak i w ekonomii (przejście od łowiectwa i zbieractwa do rolnictwa i przemysłu). Zmiany dotyczyły wielu innych aspektów, takich jak struktura władzy lub rola religii i kultury. Nie ominęły również tworzenia reguł współpracy międzyludzkiej. F. Laloux, Pracować inaczej, przeł. M. Konieczniak, Warszawa 2015, s. 23.

18 Zob. J. Wade, Changes of Mind: A Holonomic Theory of the Evolution of Consciousness, New York 1996; K. Wilber, Psychologia integralna. Świadomość, duch, psychologia, terapia, przeł. H. Smagacz, Warszawa 2000. 
do holistycznej koncepcji poznania. Dążenie do pełni przejawia się w integrowaniu wszystkich składowych naszej tożsamości: ciała, umysłu i duszy, przekroczeniu kolejnych dotychczas osobnych obszarów: życia i pracy. Jednocześnie znajduje swój wyraz również w pełni w relacji z innymi i z życiem. I tutaj, po raz kolejny, paradygmat Turkusu ujawnia swoją niespotykaną wcześniej cechę transgresyjności. Turkus wychodzi poza sferę racji na rzecz pielęgnowania relacji. Pomaga stworzyć bezpieczną, wolną od osądów przestrzeń dla różnorodności poglądów, osobowości. W takiej przestrzeni autentyczne słuchanie siebie nawzajem umożliwia dookreślenie swojej własnej tożsamości i osiągnięcie pełni w relacji z innymi ${ }^{19}$.

\section{EWOLUCYJNA TURKUSOWA ORGANIZACJA}

Trzy główne przełomy nadające turkusowej organizacji charakterystyczny rys to: samozarządzanie, pełnia i ewolucyjny cel. Turkusowe organizacje funkcjonują jako struktury holarchiczne, gniazdowe hierarchie zbudowane z zawierających się w sobie coraz to większych systemów - holonów ${ }^{20}$, które cechuje złożoność i samorzutny rozwój.

Model organizacyjny w Turkusie tworzy się samoistnie w procesie samozarządzania. Pracownicy nie działają w ramach zakresów obowiązków, lecz proponują swoje miejsce w organizacji, przyjmując na siebie różne role i funkcje w zgodzie ze swoimi preferencjami i możliwościami. Pracownicy spontanicznie tworzą zespoły zadaniowe i realizują niekiedy więcej niż jeden projekt w obrębie kilku grup roboczych. W turkusowych organizacjach przyjmuje się założenie, że asymetria informacji prowadzi do powstania nieformalnych hierarchii, co osłabia zaufanie w zespole - jeden z najcenniejszych zasobów organizacji. Pracownik bierze pełną odpowiedzialność za swoje działania podejmowane w ramach wypełnianej roli. Przedstawione wyżej założenia koncepcji samozatrudnienia są rozwijane przez pracowników danej firmy w zgodzie z ich potrzebami i specyfiką funkcjonowania organizacji.

Drugim filarem turkusowej organizacji jest dązenie do petni rozumiane jako holistyczna samorealizacja we wszystkich obszarach życia. Miejsce pracy staje się tym samym przestrzenią, a praca narzędziem, za pomocą którego członkowie organizacji pomagają sobie nawzajem wyrazić wewnętrzną wielkość i przejawiać powołanie ${ }^{21}$. Bazując na założeniach teorii integralnej $\mathrm{K}$. Wilbera, holarchia jest wielkim polem morfogenetycznym zapewniającym przestrzeń ewolucji, w ramach której może się rozwijać potencjał

19 M. Trzcionka, Turkusowa Organizacja. Żywy organizm, [w:] Wybrane aspekty przemian gospodarczych $w$ Polsce, red. M. Geise, J. Oczki, D. Piotrowski, Bydgoszcz 2018, s. 138-160.

20 Pojęcie holarchii pojawiło się po raz pierwszy w pracy Arthura Koestlera The Ghost in the Machine z 1967 r. [w:] M. Chrapko, Holakracja - nowy sposób na zwinna firmę, 26 VIII 2014, [online] https:// mariuszchrapko.com/holokracja-nowy-sposob-na-zwinna-firme-cz-2/, 29 XII 2016. [H] olon jest catością, która jest czéścia innych catości. [...] wszechświat zasadniczo sktada się z holonów, catości, które są częściami innych catości. [...] Osoba jest częścia rodziny, która jest częścia spoteczności, która jest czesścia narodu, który jest cześcia ludzkości, itd. K. Wilber, Psychologia integralna..., s. 22. 
człowieka ${ }^{22}$. Bezpieczeństwo przestrzeni budowane jest w na podstawie dwóch najistotniejszych fundamentów: bezprzemocowego modelu komunikacji oraz współdzielonych wartości. Dążenie do pełni wspiera wiele konkretnych praktyk. Są to m.in. coaching grupowy i indywidualny, praktykowanie porozumienia bez przemocy Marshalla Rosenberga, realizowanie zadań z zakresu społecznej odpowiedzialności biznesu oraz procesy związane z zasobami ludzkimi, tj. rekrutacja lub szkolenia ${ }^{23}$.

Trzecim filarem turkusowego modelu jest proces wstuchiwania się w cel organizacji, który jest narzędziem przeorientowania priorytetowych celów organizacji, definiowanego dotychczas w kategorii zysku, na cel nazwany urzeczywistnianiem życia, czyli jak to określa Laloux - osobistym oddaniem się celowi większemu niż ja sam ${ }^{24} . \mathrm{Z}$ kolei sam ewolucyjny cel organizacji to najgtębszy twórczy potencjat wniesienia czegoś nowego do życia, dokonania energetycznego, cennego wktadu dla świata ${ }^{25}$, do którego trzeba się dostroić. Zgodnie z jego ujęciem każda organizacja ma swoją energię, dynamikę i poczucie kierunku, w którym zmierza. Zadaniem pracowników staje się jego wychwycenie (a nie wytyczenie) i umożliwienie organizacji niezakłóconego rozwoju. Strategia realizacji ewoluujących celów wyłania się w naturalny sposób ze zbiorowej inteligencji samozarządzających pracowników. Procesy planowania, budżetowania i kontroli zamykają się w prostej regule wyczuwaj i reaguj. Turkusowa organizacja bazuje na uproszczonych budżetach, nie szuka doskonałych rozwiązań, nie sugeruje się ilościowo określonymi planami. Takie praktyki zawężają perspektywę wyczuwania kierunku ewolucji organizacji, oddalają pracowników od wewnętrznej motywacji, a przede wszystkim mylnie zakładają, że przyjęcie konkretnego modelu organizacyjnego ułatwi przewidywanie przyszłości ${ }^{26}$.

Organizacja przestaje być traktowana jako czyjaś własność, nawet współdzielona własność interesariuszy. Postrzegana jest ona raczej jako pole energii, wytaniająy się potencjat, forma życia, która przekracza jej interesariuszy, podażając za swym unikalnym celem ewolucyjnym. W takim paradygmacie [...] jesteśmy szafarzami organizacji. Jesteśmy narzędziem wstuchujacym się $w$ gtęboki, kreatywny potencjat organizacji, aby pomóc jej w wykorzystywaniu swej pracy w świecie ${ }^{27}$.

Krytycy koncepcji turkusowej organizacji wskazują na ryzyko, które niesie ze sobą złudzenie odkrycia sekretu skutecznego zarządzania zamkniętego w nośnej metaforze.

22 K. Wilber, Psychologia integralna..., s. 46. Według twórcy pojęcia Ruperta Sheldrake’a pole morfogenetyczne ma naturę wibrującej energii, która wchodzi w interakcje z materią (rezonans morficzny), organizując jej rzeczywistość. R. Sheldrake, Nowa biologia. Rezonans morficzny i ukryty porządek, przeł. M. Filipczuk, Warszawa 2011, s. 119-132. Wzorce energetyczne pojawiają się również w teorii atraktorów Davida R. Hawkinsa, która głosi, że pola energetyczne wchodzą w interakcje z ludzką świadomością, działając kształtująco i organizująco [w:] D.R. Hawkins, Sita czy moc, przeł. K. Dumińska, Warszawa 2009, s. 39-42.

23 M. Trzcionka, Turkusowa Organizacja..., s. 147.

24 F. Laloux, Pracować inaczej..., s. 239.

25 Tamże, s. 242.

26 Tamże.

27 F. Laloux, Pracować inaczej..., s. 267-268. 
Włodzimierz Piotrowski wskazuje, że kolejne metafory sa po prostu nowymi nazwami starych zjawisk, dawno temu opisanymi przez teoretyków zarządzania $w$ formie modeli ${ }^{28}$. Faktycznie, w trzech fundamentach turkusowej organizacji można doszukać się odniesień do istniejących teorii organizacji, w tym klasycznego nurtu ewolucyjnego postrzegającego organizację jako żywy, ewoluujący organizm zorientowany wokół procesów adaptacji do zmieniających się warunków otoczenia ${ }^{29}$ oraz nurtu krytycznego i postmodernistycznego ${ }^{30}$.

Pojawienie się nowych rozwiązań bardzo często jest odpowiedzią na niedomagania starych. Pierwszą przesłanką powstania nowego modelu organizacyjnego były ograniczenia wynikające z formalnej hierarchii zarządczej. W odpowiedzi pojawiła się koncepcja samozarządzających się zespołów eksperckich zaopatrzonych we względną swobodę decydowania ${ }^{31}$. Jednocześnie na popularności zyskiwała idea zarządzania partycypacyjnego, która tworzyła mocny grunt dla wysiłków nakierowanych na zwiększanie zaangażowania pracowników. Ramy nowej koncepcji były szerokie i dawały pracownikom możliwość wpływu na decyzje dotyczące nie tylko warunków pracy, ale nawet strategii rozwojowej firmy, w której byli zatrudnieni ${ }^{32}$. Kolejnym podejściem teoretycznym, które uzupełnia koncepcję zarządzania partycypacyjnego, jest idea upełnomocnienia pracownika (empowerment), skupiająca się na wartości dodanej wynikającej z większej autonomii i samodzielności pracowników na wszystkich szczeblach zarządzania i działania, jakie w tym zakresie mogą podjąć menadżerowie ${ }^{33}$.

Kolejny fundament Turkusu - dążenie do pełni człowieczeństwa - został umocowany przede wszystkim w klasycznej teorii zasobowej warunkującej rozwój organizacji stanem posiadania i umiejętnym wykorzystaniem zasobów materialnych

28 W. Piotrowski, Organizacje i instytucje, [w:] Teoria organizacji. Nauka dla praktyki, red. D. Latusek-Jurczak, T. Olejniczak, W. Piotrowski, Warszawa 2018, s. 47.

29 T. Burns, G.M. Stalker, The Management of Innovation, London 1961; H.E. Aldrich, Organizations Evolving, London i in. 1999.

30 A.K. Koźmiński, D. Latusek-Jurczak, Rozwój teorii organizacji. Od systemu do sieci, Warszawa 2017, s. $22-25$.

31 D. Collins, A Socio-Political Theory of Workplace Democracy: Class Conflict, Constituent Reactions and Organizational Outcomes at a Gainsharing Facility, „Organization Science” 1995, vol. 6, no. 6, s. 603-694; R.J. Hackman, The Psychology of Self-Management in Organizations, [w:] Psychology and Work: Productivity, Change, and Employment, red. M. Pallak, R. Perloff, Washington DC 1986; C. Manz, H. Sims Jr., Leading Workers to Lead Themselves: The External Leadership of Self-Managing Work Teams. „Administrative Science Quarterly” 1987, vol. 32, s. 106-128.

32 J. Cotton i in., Employee Participation: Diverse Forms and Different Outcomes, „Academy of Management Review" 1988, vol. 13, nr 1, s. 8-22.

33 H. Czubasiewicz, P. Grajewski, Koncepcja empowermentu w zarządzaniu organizacjami, „Studia i Prace Kolegium Zarządzania i Finansów, Zeszyt Naukowy” 2018, nr 162, s. 155. Por. A. Wilkinson, Empowerment Theory and Practice, „Personnel Review” 1998, vol. 27, nr 10, s. 40-56; L. Holden, The Perception Gap in Employee Empowerment: A Comparative Study of Banks in Sweden and Britain, „Personal Review” 1999, vol. 28, nr 3, s. 222-241; N.D. Lincoln i in., The Meaning of Empowerment, the Interdisciplinary Etymology of a New Management Concept, „International Journal of Management Reviews" 2002, vol. 4, nr 3, s. 271-290. 
i niematerialnych ${ }^{34}, \mathrm{w}$ koncepcjach stawiających w centrum swojego zainteresowania kulturę organizacyjną, kształtującą kontekst zarządzania i "programującą umysły” 35 , oraz w etyce biznesu, włączając koncepcję społecznej odpowiedzialności biznesu ${ }^{36}$.

Listę teoretycznych odniesień zamykają studia nad zmianą w organizacji, które zostały zintegrowane w trzecim fundamencie Turkusu - wsłuchiwaniu się w cel organizacji. Zmiana analizowana jest najczęściej w trzech osobnych ujęciach: nurcie dynamiki grupowej, lokującej zmianę na poziomie jednostki, grupy i procesów, odnoszącą się do cech osobowości, motywacji i motywowania, norm, zasad i wartości ${ }^{37}$, nurcie ewolucyjnym, zwracającym uwagę na organiczny rozwój i ciągłe przezwyciężanie wewnętrznych i zewnętrznych ograniczeń wynikających z zasobów ${ }^{38}$, oraz nurcie systemowym, kładącym nacisk na zewnętrzne źródła zmiany, jej cykliczność oraz złożonośćs ${ }^{39}$. W latach 90. studia nad zmianą wzbogaciły się o teorię złożoności, opisującą funkcjonowanie organizacji na granicy chaosu. Wzrastająca turbulencja otoczenia ulokowała zarządzanie zmianą w priorytetach zarządzania strategicznego ${ }^{40}$.

Powyższe odwołania do istniejących teorii i podejść w zarządzaniu zdają się potwierdzać zarzuty W. Piotrowskiego o złudnym nowatorstwie turkusowego modelu. Niemniej, nowości należałoby się dopatrywać nie tyle w oryginalnych założeniach teoretycznych, co w integrującym podejściu do dorobku teorii organizacji. Zgodnie z teorią integralną Kena Wilbera i koncepcją spiralnej dynamiki rozwoju organizacji Dona E. Becka i Christophera Cowana turkusowa organizacja traktuje wszystkie dostępne modele i narzędzia jako potencjały lub zasoby, do których może sięgnąć w zależności od swoich potrzeb i kontekstu, w którym aktualnie operuje. Jest ona w stanie zintegrować przywoływane założenia teoretyczne, tworząc na ich podstawie nowe, bardziej holistyczne rozwiązania.

34 J. Pfeffer, G.R. Salancik, The External Control of Organizations: A Resource Dependence Perspective, New York 1978; E.T. Penrose, Growth of the Firm and Networking, W. Warner, ed. International Encyclopedia of Business and Management, London 1996.

35 G. Hofstede, Culture's Consequences: International Differences in Work-Related Values, Beverly Hills CA, 1980; G. Hofstede, G.J. Hofstede, M. Minkov, Cultures and Organizations: Software of the Mind, $3^{\text {rd }}$ Ed., London-New York 2010; T.E. Deal, A.A. Kennedy, Corporate Cultures: The Rites and Rituals of Corporate Life, Boston 1982; E.H. Schein, Organisational Culture, „American Psychologist” 1990, vol. 43, s. 109-119.

36 E.R. Freeman, D.R. Gilbert Jr., Corporate Strategy and the Search for Ethics, Englewood Cliffs 1988; T. Donaldson, T.W. Dunfee, Toward a Unified Conception of Business Ethics: Integrative Social Contracts Theory, „Academy of Management Review” 1994, vol. 19, nr 2, s. 252-284.

37 M.R. Belbin, Management Teams: Why They Succeed or Fail, Oxford 1981; H.J. Leavitt, Some Effects of Certain Communication Patterns on Group Performance, "The Journal of Abnormal and Social Psychology" 1951, nr 46; D.C. McClelland, Achievement Motive, New York 1953; tenże, The Achieving Society, Princeton NJ 1961.

38 E.T. Penrose, The Theory of the Growth of the Firm, New York 1959.

39 T. Olejniczak, A. Pikos, Organizacja jako zmiana, [w:] Teoria organizacji.., s. 324. Zob. K. Lewin, Action Research and Minority Problems, [w:] Resolving Social Conflicts, red. G.W. Lewin, New York 1946; B. Burnes, Complexity Theories and Organizational Change, „International Journal of Management Reviews", 2005, vol.7, nr 2, s.73-90; D.C. Dunphy, D.A. Stace, Under New Management: Australian Organizations in Transition, Sydney 1990.

40 S.L. Brown, K.M. Eisenhardt, Competing on the Edge. Strategy as a Structured Chaos, Boston 1998. 


\section{TRANSGRESJA W TURKUSOWYCH ORGANIZACJACH}

Ze względu na specyfikę modelu organizacyjnego, turkusowa organizacja nie stoi przed dylematami zarządzania zmianą. Ona sama jest zmianą. Nie każda zmiana jest transgresją, ale właściwie zakomponowane działanie może przełożyć się na osiągnięcie nowych jakości, na wyjście poza dotychczasowe schematy.

Przedstawiciele turkusowych organizacji poproszeni o wskazanie granic wyobrażonych modelu organizacji pracy przywoływali przede wszystkim wynikającą z natury ludzkiej niemożność dokonania transformacji lub budowy struktury organizacji na podstawie turkusowych rozwiązań. Wątpliwości dotyczyły popularnego przekonania, które głosi, że człowiek z natury jest leniwy i nieuczciwy, dlatego wyeliminowanie struktury hierarchicznej i narzędzi zarządzania spowoduje ogólny chaos i zepsucie. Niepewność budziła również rezygnacja z tradycyjnego systemu motywacyjnego, w którym porażka spotyka się z karą, a sukces z nagrodą. Kolejną barierą wskazywaną przez respondentów była dualna perspektywa postrzegania siebie, zespołu i organizacji, która ujawniała się w podziałach ja-wy, my-wy oraz my-oni. Ostatnim przykładem granicy wyobrażonej była wiara w konieczność przybierania masek w relacjach, co miało dowodzić profesjonalizmu, wskazywać miejsce i zakres wpływu poszczególnych pracowników na funkcjonowanie zespołów i organizacji jako całości. Niektórym organizacjom udało się dokonać transgresji, inne wciąż pracują nad pewnymi aspektami Turkusu. Sukcesy tych pierwszych dają pozostałym nadzieję na udane transgresje. Dlatego niektóre z wymienionych granic dla jednych firm są już wyobrażone, dla innych wciąż rzeczywiste.

W większości badanych organizacji wątpliwości dotyczące efektywności samozarządzania zostały definitywnie rozwiane. Holarchia zdecydowanie odciąża z obowiązku zarządzania i kontroli właścicieli firmy lub dotychczasowych szefów. Powstały mniejsze, elastycznie działające zespoły, które nie potrzebują ingerencji z zewnątrz, by osiągnąć założone przez siebie cele. Pracownicy byli w stanie jasno określić swoje role, wykazywali szeroko zakrojoną samodzielność i potrafili wziąć odpowiedzialność za swoje decyzje. Odmienność założeń nowego modelu organizacyjnego dla wielu pracowników stanowiła wyzwanie. Mimo iż pracownicy przyjęli swobodę działania i łączącą się z nią odpowiedzialność z entuzjazmem, niektórzy z nich skarżyli się na niejasności związane z projektowaniem ścieżki kariery. Potrzebowali instrukcji, w jaki sposób mogliby „awansować” i tym samym osiągać wyższe dochody. Paradoksalnie z jednej strony chętnie zrezygnowali z hierarchii na rzecz holarchii, z drugiej chcieli się wspinać po drabinie awansu, by utrzymać motywację. Niektórzy zgłaszali potrzebę posiadania wizytówki z informacją, jakie stanowisko zajmują, ponieważ ułatwiłoby im to kontakt $\mathrm{z}$ interesariuszami zewnętrznymi organizacji, którzy mieli trudności w identyfikacji, jaką rolę pełnią w organizacji ich kontrahenci i na ile są w niej decyzyjni. Poza tym stanowisko można było wykazać w CV, portalach społecznościowych, określało ono tożsamość pracownika.

Na linii łączącej holarchię ze strukturami hierarchicznymi pojawiła się jeszcze jedna granica. Wyższa wydajność i sama kultura pracy samozarządzających się zespołów 
sprawia, że holarchiści we współpracy ze środowiskiem interesariuszy wewnętrznych i zewnętrznych mają poczucie niewykorzystanych możliwości i potencjału pracy. Reprezentanci badanych organizacji wskazywali na konieczność przekroczenia pewnej masy krytycznej organizacji pracujących w turkusowym modelu, by współpraca opierała się na wartościach podobnego poziomu i tym samym mogła być satysfakcjonująca dla obu stron. Większość reprezentantów wskazywała na duże trudności w uwolnieniu w pracownikach przekonania, że cel ich pracy jest nośnikiem konkretnych wartości, szczególnie kiedy pracowali w branżach B2B niemających kontaktu z konsumentem finalnym.

W obrębie kwestii dotyczących drugiego fundamentu turkusowego modelu - dążenia do pełni - respondenci wskazywali na początkowo duże kłopoty we wspólnym uzgodnieniu zestawu wartości, którymi będzie kierowała się organizacja, a także podawali w wątpliwość poziom motywacji i umiejętność samorozwoju pracowników. Obawy te okazały się jednak w wielu przypadkach nieuzasadnione. Upełnomocnienie pracowników wyzwalało w nich większą kreatywność i chęć podnoszenia kwalifikacji koniecznych dla pełniejszego realizowania obieranej przez nich roli. Zacieśniali oni więzy w zespołach i chętnie korzystali z możliwości szkoleń lub wsparcia coachingowego. Błąd lub niepowodzenie stało się okazją do pozyskiwania nowych kompetencji i wyzwalało kolejne zmiany, w tym zmiany transgresyjne. Jednocześnie zgłaszano inne ograniczenia współpracy. Pracownicy często liczyli na to, że ich potrzeby będą zaspokojone w pierwszej kolejności i tym warunkowali dalszą współpracę. Kiedy okazywało się, że korzyść indywidualna przychodzi na dalszym etapie realizacji projektu, odczuwali niezadowolenie i zniechęcenie. Reprezentanci organizacji biorący udział w badaniu zgodnie podkreślali, że w wielu przypadkach transgresja nie byłaby możliwa, gdyby nie wysoki poziom zaufania w zespole i umiejętność bezprzemocowej komunikacji. Wskazywali oni także, że rozumieją transgresyjność w tym aspekcie jako pracę nad sobą zmierzającą do pełnej samodzielności działania, również w kontekście ustalania granic i ciągłej pracy nad przestrzenią dialogu między ludźmi realizującymi pewne role we współzależności, współodpowiedzialności i współpracy z innymi.

W ostatnim analizowanym obszarze - procesie wsłuchiwania się w cel organizacji respondenci przywoływali brak zrozumienia dla samej koncepcji „wewnętrznej energii organizacji”, jej własnego nie do końca zależnego od pomysłu pracowników celu, który oni mieliby wyczuwać $\mathrm{i}$ usuwać istniejące bariery dla jego płynnego ujawniania się. Pracownikom trudno było uwierzyć również w realność zjawiska emergencji, co skutkowało oderwaniem wpływu każdego ich działania i zachowania od wewnętrznej dynamiki grupy oraz całego systemu, którego elementem jest ich organizacja. Brak rzetelności i uważności działania nawet $\mathrm{w}$ małych sprawach w sposób bardzo subtelny negatywnie wpływał na pracę zespołu i organizacji. Proces podążania za organizacją jest najbardziej enigmatycznym z filarów Turkusu i dlatego większość przebadanych firm wciąż lokuje się w obszarze działalności wyznaczonym przez granice rzeczywiste.

Wymienione przez respondentów granice wskazują, że pracownicy stoją przed licznymi wyzwaniami, które pojawiają się w praktyce funkcjonowania turkusowych organizacji. Wciąż ewoluujący system oczekuje od nich ciągłych reakcji dostosowawczych, 
które nieraz wymagają wyjścia poza oswojone schematy działania. Transgresja zwykle odbywa się na trzech poziomach: poziomie indywidulanym, organizacji oraz społecznym, gdzie każdy kolejny zawiera się w poprzednim (rysunek 2).

Rysunek 2. Poziomy transgresji w turkusowym modelu organizacyjnym

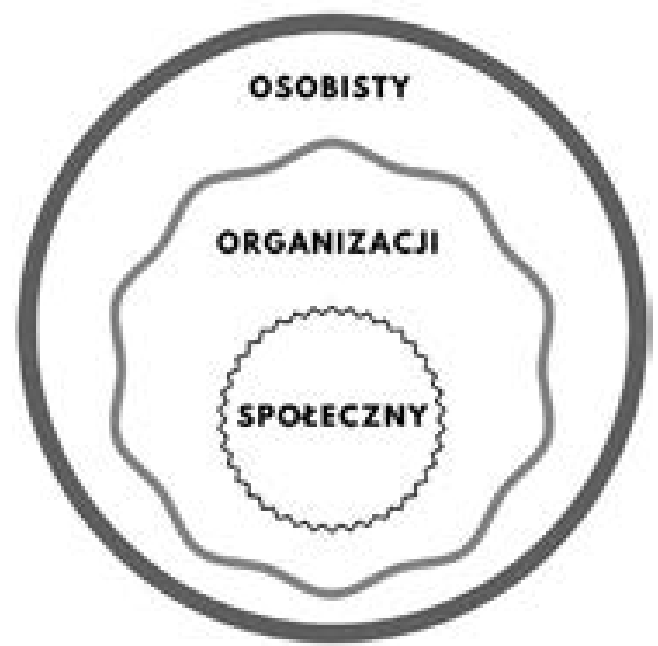

Źródło: opracowanie własne

Poziom indywidualny dotyczy człowieka działającego we wspólnocie. Człowieka, który ukształtowany przez zupełnie inne środowisko tradycyjnej, czyli hierarchicznej wspólnoty (rodziny, szkoły, pracy) wkracza na zupełnie nowy, holarchiczny teren, gdzie może i musi samodzielnie podejmować decyzje, gdzie postęp zależy od jego zaangażowania i wdrożonych unikatowych, bo autorskich rozwiązań, gdzie nie ma ram, schematów, gotowych procedur, w które można się wpisać. Człowiek sam kreuje swoją rzeczywistość zawodową, sam określa swoją rolę i komponuje zadania przybliżające go do uzgodnionego celu. Upełnomocnienie tworzy przestrzeń, w której człowiek uczy się samego siebie, tego jak być autentycznym i jak wyrażać swoje emocje i potrzeby. Odkrywa swoją tożsamość, która jest oderwana od stanowiska pracy i nie zależy od opinii otoczenia. Sam wyzwala swoją motywację, bo nie znajduje ani kar, ani nagród, które mogłyby być dla niego wskazówką właściwego kierunku. Potrzebuje on w takim razie innych zasobów, innych kompetencji, które często nie mieszczą się w programie studiów lub kursów zawodowych, a można je odkryć na ścieżce rozwoju psychologicznego i duchowego (transracjonalne techniki poznania, emergencja, mindfulness itp.).

Poziom organizacji dotyczy realizowanych przez nią wartości oraz zasad regulujących współpracę w zespole. To właśnie w tej przestrzeni pojawiają się napięcia i konflikty. W trudnym procesie ewolucji wciąż na nowo uzgadniana jest struktura organizacji. W wyniku zmieniających się warunków otoczenia konieczne jest ustalenie nowych lub przeformułowanie istniejących ról, pojawiają się i znikają realizowane zadania. Często 
okazuje się, że przyjęte rozwiązania nie działają należycie, co pociąga za sobą kolejne korekty. Aby pracownicy mogli utrzymać przyjęte założenia turkusowego modelu, konieczne są kolejne transgresje realizowane na poziomie organizacji. Stymulatorem działań transgresyjnych jest przede wszystkim akceptacja zmienności, gotowość do podejmowania wciąż nowych wyzwań oraz umiejętność zmiany perspektywy myślenia.

Ewolucyjny cel Turkusu wyraźnie widoczny jest na ostatnim poziomie transgresji, w miejscu, gdzie nowy model zderza się z tradycyjną organizacją. Cel istnienia organizacji podporządkowuje kontakty turkusowych organizacji ze światem zewnętrznym, interesariuszami i konkurencją. Z założenia turkusowe organizacje zaspokajają potrzeby klientów nie przez dostrajanie się do ustalonych norm (sondaży, grup fokusowych, mapowania wrażeń), ale przez wsłuchiwanie się w siebie ${ }^{41}$. Bardzo często działają w myśl zasad wikinomii ${ }^{42}$, dbając o dostęp i przejrzystość informacji, czym zyskują sobie przychylność kontrahentów i klientów. Dzięki większej otwartości interesariusze są bardziej skłonni do sugerowania, w jaki sposób lepiej realizować cel organizacji. Podobna koncepcja dyktuje kryteria doboru dostawców. Liczy się nie tylko cena i jakość oferty, ale dopasowanie do wartości i ewolucyjnego celu opartego na wartościach. Kiedy organizacja oddaje się mu bez reszty, konkurencja nie istnieje. Co więcej, model turkusowy jest transparentny, a dostęp do informacji na tyle otwarty, żeby zachęcić inne organizacje do naśladownictwa ${ }^{43}$. W turkusowych organizacjach może pojawić się niepewność związana z odbiorem ich modelu funkcjonowania ze strony otoczenia. Bardzo często słyszy się, że Turkus to fanaberia, chwilowa moda, która przepadnie w zderzeniu $\mathrm{z}$ „prawdziwą” naturą człowieka, który jako pracownik jest leniwy i nieuczciwy. Co prawda oferta rekrutacyjna przyciąga kandydatów do pracy przez wzgląd na oryginalność modelu, indywidualizm, tendencję rozwojową dążącą do wzbogacania kultury, ale kiedy pojawiają się pierwsze bariery związane z własnymi ograniczeniami, tarciami w zespole współpracowników czy wyzwaniami, przed którymi staje organizacja, pracownicy mają skłonność do zrzucania odpowiedzialności na założenia modelu, które winią za bieżący chaos i bałagan. Podobna postawa charakteryzuje kontrahentów, których oczekiwania nie zostały należycie zaspokojone.

Reprezentanci organizacji wyrazili obawy, iż porażka w budowaniu lub transformacji istniejących firm w duchu turkusowej rewolucji, może sprawić, że dobrze rokujący model organizacyjny podzieli los niesławnej koncepcji społecznej odpowiedzialności biznesu, która traktowana przez niektóre przedsiębiorstwa jako narzędzie marketingowe przestała być nośnikiem szczytnych wartości.

Przeprowadzone wywiady są zgodne z tezami Kozieleckiego dotyczącymi relatywnego charakteru determinant transgresji. Jego zdaniem nie istnieją absolutne

$41 \quad$ F. Laloux, Pracować inaczej..., s. 252.

42 Pojęcie wikinomii można rozumieć jako spontaniczną, masową współpracę ludzi w rozwiązywaniu problemów, która odbywa się z wykorzystaniem nowoczesnych technologii komunikacyjnych. Działania w zakresie wikinomii opisuje pięć podstawowych zasad: współpraca, otwartość, współdzielenie (wymiana wiedzy), uczciwość, współzależność. Więcej na ten temat: D. Tapscott, A. Williams, Makrowikinomia. Reset świata i biznesu, przeł. D. Bakalarz, Warszawa 2011.

43 F. Laloux, Pracować inaczej..., s. 236. 
stymulatory transgresji, które w każdych okolicznościach i w stosunku do każdej osoby zwiększają skuteczność działania. Nie ma też takich przeszkód. To samo zjawisko może być akceleratorem bądź przeszkodą ${ }^{44}$.

Biorąc pod uwagę treści przekazane przez respondentów, podstawowym źródłem przeszkód i stymulatorów transgresji staje się poziom osobisty, a zależy on od wyznawanych wartości i stopnia możliwości percepcyjnych, umiejętności wyjścia poza schemat, dostrzeżenia hamujących przekonań, niechęci opuszczania strefy komfortu (lęki, niepewność). Turkus potrzebuje lub kształtuje ludzi o dobrze osadzonej samoocenie, posiadających realistyczne rozeznanie dotyczące własnych kompetencji, umiejących nimi skutecznie zarządzać. Ludzie Turkusu potrafią oddzielić pracę od swojego ego, nie utożsamiają się z zajmowanym stanowiskiem, ale pełnią szereg ziarnistych ról w organizacji. Sens pracy odnajdują w realizacji ewolucyjnego celu, nie szukają w niej potwierdzenia własnej wartości na tle innych pracowników. Potrafią oni przekroczyć system nagród i kar ograniczający ich inwencję twórczą i poziom zaangażowania oraz są w stanie przyjąć pełnię odpowiedzialności za przyjęte na siebie zobowiązania. Potrafią stworzyć dla siebie i dla innych przestrzeń, w której panuje obopólne zaufanie, gdzie można założyć, że ludzie są z natury uczciwi, pracowici i inteligentni oraz że mają dobre intencje. Kiedy rzeczywistość nie spełnia oczekiwań, pojawia się przestrzeń na dialog i zrozumienie.

Rozwój osobisty napędzany przez transgresje typu P staje się warunkiem koniecznym dla transgresyjności organizacji na pozostałych poziomach. Zasoby własne pracownika wsparte wysokimi umiejętnościami komunikacyjnymi pozwalają na ewolucję turkusowego modelu oraz umożliwiają urzeczywistnienie celów organizacji.

\section{KOMUNIKACJA PALIWEM TRANSGRESJI W TURKUSOWYCH ORGANIZACJACH}

Każdy z trzech filarów Turkusu wymaga wysokich kompetencji w zakresie porozumiewania się, szczególnie w aspekcie artykułowania swoich potrzeb, zakreślania granic, informacji zwrotnej oraz bezprzemocowego rozwiązywania sporów. Komunikacja $\mathrm{z}$ innymi ludźmi sama $\mathrm{w}$ sobie jest ogromnym wyzwaniem: filtr nadawcy, ograniczenia języka, błędy w wyrażeniu istoty rzeczy, odbieranie komunikatu poprzez filtry odbiorcy, emocje zaburzające proces percepcji. Wymienione ograniczenia, często postrzegane jako granice, można przekroczyć dzięki świadomości tego, co dzieje się w procesie komunikacji. Prowadzenie komunikacji w konstruktywny sposób zakłada świadomość, że niezależnie od naszych intencji te wszystkie filtry istnieją, komunikowanie się jest sztuką wymagającą nakładu energii. W większości organizacji, które wzięły udział w badaniu, konstruktywna komunikacja opiera się na założeniach Porozumienia bez przemocy Marshalla B. Rosenberga.

Rosenberg stworzył sposób komunikacji opartej na szacunku dla doświadczenia każdego, na świadomości i uznaniu potrzeb swoich i innych ludzi. Idea ta bazuje na

44 J. Kozielecki, Psychotransgresjonizm..., s. 186. 
systemie przekonań o człowieku, który zaspokaja swoje potrzeby poprzez działania, wybierając świadomie lub nieświadomie najlepsze dostępne dla niego w danym momencie strategie. Człowiek posiada zdolność do empatii, jest współzależny i zdolny do zmiany. Ideą NVC jest docenienie uniwersalnych potrzeb aktualizujących się w różnych sytuacjach życiowych. Brak świadomości tych potrzeb powoduje, że jednostka działa „na oślep”, wybierając strategie, które krzywdzą ją samą lub innych. Dzięki uzyskaniu świadomości potrzeb może ona wybierać lepsze działania; lepsze, czyli takie, które zaspokajają te potrzeby. Taka zmiana perspektywy komunikacji daje szansę na pełniejsze zrozumienie i współpracę, jednocześnie kwestionując zarówno język będący w użyciu, jak i funkcjonujące normy komunikacji. Transgresja w tym obszarze otwiera zupełnie nowe możliwości.

Zorientowana w ten sposób komunikacja kreowałaby nową rzeczywistość, gdy w sytuacji bycia publicznie nazwanym kłamcą adresat zamiast pozwu do sądu o zniesławienie z ciekawością i otwartością zapytałby o przesłanki wyrażenia takiej opinii. Analogicznie można przeanalizować kontekst motywacji pracownika. W klasycznym, statycznym opisie sytuacji komunikat można sformułować następująco: „Osoba A nie jest zaangażowana”. Człowiek jest postrzegany w NVC jako zmieniająca się jednostka, niepoddająca się statycznemu opisowi ze względu na złożoność potrzeb, sytuacji i zachowań, wybierająca dostępne strategie w danym momencie. Zdanie „Osoba A nie jest zaangażowana” opisuje jakąśs część rzeczywistości, jakieś określone zachowanie lub jego brak. Nie daje nam pełnego opisu tego, co się dzieje dla danej jednostki ani blokad, na jakie natrafia ona w swojej pracy, i prowadzi do niezweryfikowanego wniosku, że ,jednostkę trzeba zmotywować".

Człowiek, według NVC, kształtuje siebie w dynamicznym procesie odpowiadania na wyzwania rzeczywistości. Stąd pogląd, że jedyną siłą motywującą jest zaspokojenie własnych potrzeb. W sytuacji gdy potrzeby organizacji stają się tożsame z potrzebami jednostki, jeśli może ona w jej ramach realizować potrzebę sensu i celu własnego życia, następuje głęboka i wewnętrzna motywacja. Dążenie do pełni jednostki, rozumiane jako realizacja jej pełnego potencjału oraz przekraczanie siebie, zawiera się w dążeniu do pełni całej organizacji, a ewolucyjny cel realizowany na poziomie jednostki jest wyzwaniem dla realizacji celu i sensu istnienia człowieka. Każdy pracownik sam nadaje sens swojej pracy, w zależności od swoich uzdolnień i talentów. Komunikacja, która daje człowiekowi wolność i poczucie wyboru, sprawia, że człowiek może realizować się w zadaniach, które podejmuje.

Powyższy przykład obrazuje wpływ zmiany perspektywy komunikacyjnej na relacje międzyludzkie. Diagnoza „Osoba A nie jest zaangażowana”, która wskazywała konieczność zastosowania instrumentów pobudzających motywację pracownika, zostaje zamieniona na pytanie: „W jaki sposób chcesz realizować w tej organizacji swoją potrzebę sensu i znaczenia?". Każdy człowiek powinien mieć wolność w wyborze strategii realizującej potrzeby sensu i znaczenia swojej pracy zarobkowej. Na poziomie jednostkowym oznacza to zrozumienie i przekraczanie naszych spotecznych uwarunkowań, tak byśmy mogli żyć $w$ wolności. Dopiero wtedy możemy stać się takimi osobami, jakimi chcemy być, stworzyć dla siebie nowe możliwości i sami decydować, co robić ze swoim życiem, być wświecie nawet 
wtedy, gdy nic się nie zmienito i pracować nad tym, aby zaistniaty zmiany, jakich chcemy ${ }^{45}$. Podstawowym narzędziem porozumienia są cztery komponenty (cztery kroki):

1) fakty/obserwacje,

2) uczucia,

3) potrzeby,

4) prośby.

Fakty/obserwacje to elementy rzeczywistości, które strony dialogu postrzegają w ten sam sposób. Stanowią one bazę i podstawę rozmowy. Odróżniamy je od interpretacji, czyli naszych idei i wyobrażeń oraz „filmów mentalnych” na temat tego, co się dzieje.

Uczucia są traktowane jako sygnały o tym, co się w danym momencie dzieje. Doceniamy informacyjną wartość uczuć bez oceniania ich jako dobre czy złe. Emocje zapewniają stały, dynamiczny dopływ informacji o tym, jakie znaczenie ma dla jednostki to, co się dzieje. Pobudzają do działania, aby przedłużać stan, kiedy doświadczamy przyjemnych emocji lub zmieniać sytuację, w której doświadczamy nieprzyjemnych. Są traktowane jako dar, dzięki któremu jednostka może odczuwać bogactwo życia i wchodzić w kontakt z potrzebami.

Potrzeby motywują każde działanie i są jego korzeniami. Określenie potrzeby, czyli abstrakcyjnej wartości, która jest uniwersalna i służy życiu, umożliwia uwolnienie się od obwiniania innych i wzięcie osobistej odpowiedzialności zarówno za zaspokojenie swoich potrzeb, jak i za strategie, na które się decydujemy, aby te potrzeby zaspokoić. Poprzez skupienie sie na ludzkich potrzebach wyraźnie dostrzegamy opresyjne elementy $w$ istniejacych spoteczeństwach. Stworzyliśmy systemy, które czesto przeciwstawiaja sie ludzkim potrzebom, jednocześnie utrwalając w nas tendencje do wspótdziatania $z$ istniejącymi strukturami, mimo że sa opresyjne ${ }^{46}$.

Pozytywne, jasne, możliwe do spełnienia prośby kierowane do innych są wskazaniem, czego naprawdę chcemy. Otwartość w wyrażaniu próśb zwiększa szanse ich spełnienia. Prośba nie jest tożsama ani z „pobożnym życzeniem” przez wzgląd na swój konkretny charakter (np. „potrzebuję szacunku” zamiast „czy możesz zapukać, jak wchodzisz do mojego pokoju?”), ani z żądaniem, które nie przewiduje odmowy.

Takie narzędzie komunikacji ogromnie sprzyja wzajemnemu zrozumieniu i znalezieniu wspólnych działań. Na przeszkodzie stoją nawyki komunikacyjne - brak bezpieczeństwa w otwartym mówieniu o sobie i o swoich pragnieniach, brak świadomości potrzeb oraz trudne emocje: wstyd, poczucie winy, złość. Dlatego NVC to praktyka zmiany nawyków komunikacyjnych. W sytuacji pracy, gdzie panuje stres, nacisk na rezultaty, presja codziennych zobowiązań i natłoku informacji, taka komunikacja jest prawdziwym wyzwaniem.

Twórca NVC, Marshall Rosenberg, powtarzał za Ruth Bebermeyer, że słowa mogą być jednocześnie oknami lub murami ${ }^{47}$. „Mury” rozumiane są jako blokady komuni-

45 M. Kashtan, Niezwykle świadome życie. Świat skrojony na miarę ludzkich potrzeb. T. I: Od oddzielenia do jedności, przeł. D. Pilas-Wiśniewska, A. Klimek, Poznań 2017, s. 135.

46 Tamże, s. 134.

47 M.B. Rosenberg, Porozumienie bez przemocy: o jezzyku życia, przeł. M. Kłobukowski, Warszawa 2017. 
kacji, uniemożliwiające efektywne zrozumienie, są granicami rozumianymi w sensie negatywnym - odgradzającym nadawcę od odbiorcy. Na poziomie indywidualnym są to wszelkie osądy i przekonania na temat siebie, swojej roli i możliwości, zdefiniowanej tożsamości. Na poziomie relacyjnym - osądy na temat drugiego człowieka. Na poziomie organizacji - przekonania na temat ról, hierarchii, struktury, decyzyjności, autoryzacji. „Okna” symbolizują umiejętność zobaczenia tego, co jest poza słowami, czyli potrzeb, wartości, pragnień, dążeń, właśnie tego, co w opisie Turkusu nazywa się „dążeniem do pełni” czy „ewolucyjnym celem”. To linia demarkacyjna rozumiana pozytywnie jako granica wyznaczająca własną i cudzą przestrzeń, szanującą autonomię i upełnomocnienie każdej jednostki i jej własną przestrzeń realizacji i wartości. Kompetencje konstruktywnej komunikacji pozwalają zobaczyć słowa „mury” jako wyobrażeniowe, dzięki umiejętności odczytania tego, co jest poza słowami - intencji innej osoby, jej wartości, celów i dążeń. W tej perspektywie każdy komunikat, niezależnie od dosłownego brzmienia, będzie zawierał prośbę o zmianę zastanej rzeczywistości.

W ten sposób traktowane są również konflikty. Ujawniony konflikt opisuje niezaspokojone potrzeby stron i jest okazją do zmiany na poziomie osobistym lub strukturalnym tak, aby rzeczywistość, którą tworzymy, w lepszy sposób odpowiadała na nasze potrzeby. Na przykład w komunikacie „Co za niedorzeczny pomyst!” zawarte jest oskarżenie o niekompetencję. Taki komunikat często staje się końcem dialogu, zapoczątkowując wzajemne oskarżenia w walce o racje. Tymczasem możemy takie zdanie usłyszeć jako wyraz troski o jakość pracy i wezwanie do szukania lepszych pomysłów na rozwiązanie danej sytuacji problemowej. Wtedy dialog skupia się zarówno na zrozumieniu problemu, jak i szukaniu rozwiązań. Taki komunikat, który zwykle jest granicą zrozumienia, staje się drogą do przekroczenia jej. Wymaga to jednak umiejętności zarządzania własnymi emocjami i popatrzenia z dystansu na to, co się dzieje w trakcie interakcji.

Doświadczeniem niemal każdego człowieka jest sytuacja, kiedy jest krytykowany, jest do czegoś zmuszany, nie widzi możliwości wyboru ani wpływu na sytuację. Rezultatem takiego doświadczenia jest opór i niechęć do współpracy. Człowiek może odczuwać podobny opór, kiedy przypisuje się mu statyczne określenia - zaangażowany, leniwy, niekompetentny - trwałe cechy na podstawie jednostkowych zdarzeń, określenia, które nie odzwierciedlają złożoności doświadczenia człowieka. Często też zdarza się, że przypisuje mu się intencje, których nie ma - słuchający diagnozuje, interpretuje, ukazuje wyższość, bez pełnego zrozumienia doświadczenia innego. Te wszystkie zjawiska, tak typowe w komunikacji, stają się barierami porozumienia. Okazuje się, że zmiana sposobu mówienia zmienia sposób myślenia. [...] badania pokazują, że jezyki, jakimi mówimy, nie tylko odzwierciedlają lub wyrażają nasze myśli, ale również ksztattują te wtaśnie myśli, które wyrażamy. Struktury, które istnieja w naszych jezykach, gtęboko ksztattuja sposób, w jaki konstruujemy rzeczywistośćs ${ }^{48}$.

Zarówno na bardzo praktycznym poziomie samozarządzania, jak i w dążeniu do pełni czy realizacji ewolucyjnego celu organizacji, narzędzia NVC wpisują się

48 M.R. Miyashiro, Empathy Factor. Your Competitive Advantage for Personal, Team, and Business Success, Encinitas, CA 2011, s. 41. 
w codzienną praktykę Turkusu. Jedyna możliwa zmiana odbywa się równolegle na kilku płaszczyznach - osobistego wyzwolenia i dzięki temu zmiany społecznej. Zmieniając sposób mówienia, zmieniamy sposób myślenia, a zmiana myślenia demaskuje kolejne obszary przemocy. Dzięki temu możemy rozszerzać zmianę w organizacjach - od zmiany sposobu mówienia poprzez zmianę kultury komunikacji, aż po zmianę struktury organizacyjnej

\section{POWSTANIE TURKUSOWEJ ORGANIZACJI NA PRZYKŁADZIE LEANCE}

Leance jest organizacją, która prowadzi w Krakowie żłobek i przedszkole Krasnal, oferuje warsztaty z zakresu m.in. konstruktywnej komunikacji NVC, rozwiązywania konfliktów, zarządzania relacjami, realizuje facylitacje w konflikcie, mediacje i coaching, a także wynajmuje przestrzeń coworkingową. Leance rozpoczęła funkcjonowanie w sierpniu 2016 r., obecnie tworzy ją 10 osób, współpracując z 10 osobami spoza organizacji. Leance jest organizacją umocowaną na fundamencie konstruktywnej komunikacji, identyfikującą się z wartościami realizowanymi w turkusowym paradygmacie. Współpracownicy opisują swoje doświadczenia związane z budowaniem organizacji w samozarządzającym się modelu jako dialogiczną podróż ku wolności i odpowiedzialności: Dla mnie wejście do turkusowej organizacji to jak bycie marynarzem, który stoi na brzegu kontynentu, widzi ocean $i$ wie, że może go przeptynąc, i jednocześnie, który dotychczas plywat wzdtuż brzegu, pomiędzy dwoma znanymi portami. I ma przekonanie, że to ten wtaściwy moment na wyptynięcie na ocean, $i$ widzi innych chętnych do wspólnego podróżowania. Swoboda i szerokie możliwości w pierwszym momencie zachwycaja, ale uzgodnienie, w którym kierunku poptyniemy, odnalezienie swojej roli na statku i wytrwanie w niej albo uzgodnienie, kto inny ja przejmie, wymaga od każdego we wspólnocie gtębokiego spotkania ze soba i komunikowania tego, co dla niego ważne. To droga petna wyzwań, sukcesów i porażek. $Z$ możliwościa zejścia ze statku w każdej chwili. Innymi słowy: Turkus to wolność wyboru. Angażuje tyle sit, na ile akurat mam zasobów. $Z$ wolnościa wiąże się odpowiedzialność.

Osoby tworzące Leance prezentują pogląd, że sposób sprawowania władzy na podstawie hierarchii - nadanego autorytetu i pozycji siły - wyczerpał się. W rzeczywistości rozproszonej wiedzy, niejednoznacznej, złożonej, zmiennej rzeczywistości komunikacja ma podstawowe znaczenie dla sprawnego współdziałania w zespołach i efektywności podejmowanych działań. Stąd komunikacja, bazująca na uznaniu kompetencji i perspektywy wszystkich członków w zespole, jest podstawowym narzędziem współpracy i budowania struktury.

Wszyscy członkowie, w odpowiedzi na swoje potrzeby, tworzyli strukturę organizacji, bazując na trzech kręgach zaangażowania i aktywności oraz rolach, które poszczególne osoby chcą pełnić w zależności od swoich kompetencji i poczucia sensu.

Statut określa sposób podejmowania decyzji - każda zaangażowana w określone działanie osoba ma prawo podjąć decyzję jej dotyczącą. W procesie podejmowania 
decyzji ma obowiązek poinformować wszystkich interesariuszy, czyli osoby, na które dana decyzja będzie oddziaływać, oraz przejść przez proces dyskutowania decyzji, czyli zbierania opinii na jej temat. W praktyce oznacza to wysłanie opisu podejmowanej decyzji na listę mailingową z określeniem czasu „zbierania sprzeciwów”, czyli granicznej daty, do której osoba, która z daną decyzją się nie zgadza, ma czas na odpowiedź i na wejście w dialog. Pozwala to na szybkie i skuteczne podejmowanie decyzji, na wyjaśnienie tych aspektów, które są niejasne oraz wyrażanie opinii tych osób, które w jakikolwiek sposób chcą zaangażować swoją energię w daną sprawę.

Dzięki konstruktywnej komunikacji sprzeciw nie blokuje decyzji, lecz wyrażone obawy czy niepokoje pozwalają wziąć pod uwagę więcej czynników, uwzględnić wielość perspektyw lub lepiej określić złożoność problemu. Współpracownicy definiują konflikt jako „brak porozumienia, odmienne wizje i pomysły, ale także szansę na dialog” oraz „okazję do głębszej rozmowy i przyjrzenia się temu, co działa, a co nie działa” i wskazują, że jego źródłem jest często brak jasnej komunikacji, związany z „pośpiechem i brakiem uważności. Kiedy zaczynamy rozmawiać, konflikty zazwyczaj znikają”.

Dlatego to, co jest bazą funkcjonowania Leance i co okazało się niezbędne, to praktyczne umiejętności:

- komunikowania, szczególnie w sytuacjach konfliktowych;

- mediacji i rozwiązywania konfliktów, tak aby potrzeby wszystkich stron zostały uwzględnione; (istotą mediacji jest zobaczenie, że pod spodem naszych działań mamy takie same pragnienia. Ta perspektywa pomaga skorygować działania tak, aby służyły lepiej obu stronom konfliktu);

- dawania informacji zwrotnej dotyczącej naszych działań;

- odwoływania się do wspólnych wartości, tożsamości organizacji, kim jesteśmy, jak chcemy współdziałać;

- prostego i klarownego procesu decyzyjnego.

Funkcja przełożonego w klasycznej organizacji dotyczy pięciu obszarów: planowania celów ogólnych i szczegółowych, organizowania pracy, wspierania i rozwoju pracowników, koordynacji działań i kontroli. W Leance każdy pracownik, opierając się na wyznaczonych wartościach, swojej roli i kompetencji, planuje swoje działania i zaprasza do realizowanych przez siebie projektów poszczególne osoby. Zespół projektowy sam organizuje swoją pracę, najlepiej będąc w stanie określić posiadane zasoby oraz oczekiwania klienta. Proces informacji zwrotnej i mediacje regulują obszary rozwoju pracowników i kontroli działań.

\section{FEEDBACK JAKO NARZĘDZIE ROZWOJU I KORYGOWANIA NIEPOŻĄDANYCH ZACHOWAŃ}

Przyjęcie informacji zwrotnej bywa trudnym doświadczeniem dla obu stron. Przykładem z praktyki funkcjonowania Leance jest sytuacja, w której zespół przygotowywał się do zorganizowania warsztatów w ramach Tygodnia Przedsiębiorczości. Terminy warsztatów zostały już ustalone i nagle, tydzień przed imprezą, jeden z trenerów zrezygnował. 
Decyzję swą uzasadnił faktem, że zmieniły się jego plany. Napięcie w zespole rosło. Osoba, która była odpowiedzialna za przeprowadzenie warsztatu, zrezygnowała, nie wiadomo, co zrobić: odwołać warsztat czy może poszukać zastępstwa. W takiej sytuacji najwygodniej byłoby mieć szefa, który podjąłby właściwą decyzję. Nikt nie zgłaszał chęci podjęcia się rozwiązania tego problemu. Zespół zdecydował o przygotowaniu informacji zwrotnej, która, jak się później okazało, miała bardzo dużą moc regulacyjną. Zawierała ona informację, jak ta sytuacja wpłynęła na zespół, w jak bardzo niekomfortowej sytuacji znaleźli się jego członkowie wobec siebie nawzajem oraz wobec klienta. Prócz tego wzywała ona trenera do podjęcia konkretnych działań. Zgodnie z czterema krokami NVC informacja zwrotna mogła zostać rozbita na następujące komponenty:

1) FAKT: Kiedy odwołujesz warsztat;

2) JAK TO NA MNIE WPŁYWA: jestem bardzo sfrustrowana;

3) POTRZEBA: bo potrzebuję współpracy i odpowiedzialności;

4) PROŚBA: i proszę, zajmij się konsekwencjami swojej decyzji, czyli znalezieniem zastępstwa lub poinformowaniem wszystkich o odwołaniu.

Mimo iż struktura komunikatu może wydawać się sztywna i trywialna, to jak poinformował trener po otrzymaniu informacji zwrotnej, było to dla niego trudne doświadczenie, a stan, w jakim pozostawił zespół, zmotywował go do wzięcia odpowiedzialności za swoje działania poprzez podjęcie odpowiednich kroków.

Doświadczenie Leance wskazuje, że możliwa jest ewolucyjna zmiana paradygmatu, od zmiany relacji osobistych aż do struktury organizacji. Nie przychodzi ona jednak z łatwością, ponieważ pojawia się konieczność nieustannego rewidowania, czy granice w naszych głowach są realne czy wyobrażeniowe.

\section{PODSUMOWANIE}

Obraz współczesnej organizacji kreśli przede wszystkim jej zdolności adaptacji do płynnej rzeczywistości oraz ekspansji na wciąż nowe tereny. Adaptacyjność jest odpowiedzią na wyzwania pochodzące ze zmiennego i złożonego otoczenia. Z kolei ekspansywność organizacji (przedsiębiorstwa) przejawia się w wieloaspektowym rozszerzaniu granic swojej dotychczasowej działalności: geograficznym, finansowym, asortymentowym, procesowym etc., a to przekraczanie określone jest pojęciem transgresji. Uznanie adaptacyjności i ekspansywności za podstawowe atrybuty współczesnej organizacji wiąże się automatycznie z przyjęciem humanistycznej perspektywy patrzenia na organizację, w której nie kapitał rzeczowy, finansowy czy nowoczesna technologia odgrywają znaczącą rolę, ale ludzie, którzy zasobni w kompetencje mogą wyzwalać oraz realizować transgresję. Pozostałe czynniki wytwórcze stają się arsenałem narzędziowym człowieka, który planuje, realizuje i rewiduje proces adaptacji i ekspansji organizacji.

Obecnie rynek pracy cechuje głęboki dualizm. W niektórych branżach walczy się o pozyskanie i utrzymanie wysoko wykwalifikowanego pracownika (np. IT), w innych pracownik traktowany jest jako doskonale substytucyjny zasób. Niepodważalny jest jednak fakt, że strategie zarządzania zasobami ludzkimi skupione są na podnoszeniu 
wydajności pracy wszelkimi możliwymi sposobami. Dlatego podział branżowy schodzi na dalszy plan; pracownik wydajny to pracownik zaangażowany i kreatywny, czyli znajdujący spełnienie w swojej pracy. Pracodawcy prześcigają się niekiedy w tworzeniu warunków, które spełniać będą oczekiwania pracowników, proponując rozbudowane pakiety socjalne lub fizyczne przestrzenie relaksu w miejscu pracy. Nie zmienia to jednak faktu, że pracownicy wciąż są biorcami, a nie twórcami warunków, w których mogą się zawodowo spełniać. Odmienność znaczeń, jakie każdy nadaje kategorii „satysfakcjonująca praca", nie wróży powodzenia tym próbom.

Wsparciem może okazać się turkusowy model organizacyjny, w który wpisana jest autonomia działania, poszanowanie dla autentyczności i uznanie dla indywidualnych potrzeb. Wyjaśnia to po części rosnącą popularność turkusowych organizacji. Dla potencjalnych pracowników atrakcyjne wydają się też przypisane turkusowemu modelowi wartości, takie jak wolność, zaufanie, odpowiedzialność oraz dążenie do pełni, szacunek i akceptacja. Założenia turkusowego modelu nie są receptą na sukces w pogoni za wzrostem wydajności pracy. Turkus nie stanowi odpowiedzi na pytanie, jakimi nowymi środkami skłonić pracownika do większego zaangażowania w wypełnianie swoich obowiązków lub podjęcia nowych wyzwań i coraz to dalej idących wyrzeczeń w interesie firmy. W praktyce okazuje się bowiem, że zbudowanie modelu współpracy na takim zestawie wartości jest karkołomne i wymaga poważnych zmian w sposobie myślenia o sobie i innych w procesie tworzenia zupełnie nowej rzeczywistości. Osoby sięgające po turkusowe rozwiązania żywią nadzieję, że taka rzeczywistość może stać się faktem. Wiara ta motywuje je do przekraczania rozlicznych ograniczeń, transformacji własnych przekonań w drodze do bardziej humanistycznej, opartej na wartościach koncepcji organizacji. Przeskoku ewolucyjnego z Zieleni do Turkusu nie można porównać do żadnego innego przełomu w ewolucji modeli organizacyjnych. Modele do Zieleni włącznie nazywane są przez Laloux modelami „pierwszej warstwy”. Turkus stanowi otwarcie listy „drugiej warstwy”. Podstawowa różnica między tymi poziomami polega na odmiennym postrzeganiu własnych racji. Przedstawiciele organizacji „pierwszej warstwy” uważają swój światopogląd za jedyny słuszny, szukając niedomagań w pozostałych. Turkusowe organizacje bardziej niż racje cenią relacje, co znajduje swoje odbicie w potrzebie pogłębionego kontaktu budowanego na bezprzemocowym porozumieniu uwzględniającym potrzeby wszystkich stron. Mało tego, język NVC staje się także językiem metakomunikacji, daje bowiem narzędzia do tego, aby mówić o samym procesie, o tym, jakie były intencje nadawcy i jak te intencje zostały zrozumiane oraz o tym, jakie reakcje wywołują poszczególne słowa, które z nich i z jakiego powodu przenoszą dodatkowe dla odbiorcy, a niezamierzone przez nadawcę znaczenia. Zgodnie z NVC język jest konstruktem mentalnym opisującym obraz świata zapisany w mapie zarówno odbiorcy, jak i nadawcy. Ta reprezentacja świata nie jest tożsama ze światem rzeczywistym, lecz jest jego obrazem. Opisywany obraz wraz z językiem opisu daję szansę jednostce nabrać dystansu do procesu komunikacji i modyfikować swój język na podstawie nowych danych.

Wydaje się zasadnym spojrzeć szerzej na transgresję, nie jako na proces pokonywania granic, ale ich przesuwania. Dzięki transgresji powstają nowe przestrzenie, wciąż na 
nowo kreślona jest mentalna mapa myśli człowieka o sobie i o świecie. Wiara w istnienie tych przestrzeni jest oknem, przez które je widać. Sama transgresja jest drzwiami prowadzącymi w rejony nowych znaczeń i możliwości. Natura zna granice, ale w każdym ruchu dąży do ich zacierania.

\section{BIBLIOGRAFIA}

Aldrich H.E., Organizations Evolving, London i in., 1999.

Barker J., Tightening the Iron Cage: Concertive Control in Self-Managing Teams, „Administrative Science Quarterly" 1993, vol. 38, nr 3.

Beck D.E., Cowan Ch., Spiral Dynamics: Mastering Values, Leadership, and Change: Exploring the New Science of Memetics, Malden 2011.

Belbin M.R., Management Teams: Why They Succeed or Fail, Oxford 1981.

Brown S.L., Eisenhardt K.M., Competing on the Edge. Strategy as a Structured Chaos, Boston 1998.

Burnes B., Complexity Theories and Organizational Change, „International Journal of Management Reviews" 2005, vol. 7, nr 2.

Burns T., Stalker G.M., The Management of Innovation, London 1961.

Chrapko M., Holakracja - nowy sposób na zwinna firmę, 26 VIII 2014, [online] http://mariuszchrapko.com/holokracja-nowy-sposob-na-zwinna-firme-cz-2-z-6/, 29 XII 2016.

Collins D., A Socio-Political Theory of Workplace Democracy: Class Conflict, Constituent Reactions and Organizational Outcomes at a Gainsharing Facility, „Organization Science” 1995, vol. $6, \mathrm{nr} 6$.

Cotton J., Vollrath D., Froggatt K. i in., Employee Participation: Diverse Forms and Different Outcomes, „Academy of Management Review” 1988, vol. 13, nr 1.

Czubasiewicz H., Grajewski P., Koncepcja empowermentu w zarzadzaniu organizacjami, „Studia i Prace Kolegium Zarządzania i Finansów, Zeszyt Naukowy" 2018, nr 162.

Deal T.E., Kennedy A.A., Corporate Cultures: The Rites and Rituals of Corporate Life, Boston 1982.

Donaldson T., Dunfee T.W., Toward a Unified Conception of Business Ethics: Integrative Social Contracts Theory, „Academy of Management Review” 1994, vol. 19, nr 2.

Dunphy D.C., Stace D.A., Under New Management: Australian Organizations in Transition, Sydney 1990.

Freeman E.R., Gilbert D.R. Jr., Corporate Strategy and the Search for Ethics, Englewood Cliffs 1988.

Hackman R.J., The Psychology of Self-Management in Organizations, [w:] Psychology and Work: Productivity, Change, and Employment, red. M. Pallak, R. Perloff, Washington DC 1986.

Hofstede G., Hofstede G.J., Minkov M., Cultures and Organizations: Software of the Mind, $3^{\text {rd }}$ Edition, London-New York 2010.

Holde, L., The Perception Gap in Employee Empowerment: A Comparative Study of Banks in Sweden and Britain, „Personal Review” 1999, vol. 28, nr 3. 
Kashtan M., Niezwykle świadome życie. Świat skrojony na miare ludzkich potrzeb. T. I: Od oddzielenia do jedności, przeł. D. Pilas-Wiśniewska, A. Klimek, Poznań 2017.

Kozielecki J., Koncepcja transgresyjna cztowieka. Analiza psychologiczna, Warszawa 1987.

Kozielecki J., Psychotransgresjonizm. Nowy kierunek w psychologii, Warszawa 2001.

Kozielecki J., Transgresja i kultura, Warszawa 1997.

Koźmiński A.K., Latusek-Jurczak D., Rozwój teorii organizacji. Od systemu do sieci, Warszawa 2017.

Laloux F., Pracować inaczej, przeł. M. Konieczniak, Warszawa 2015.

Leavitt H.J., Some Effects of Certain Communication Patterns on Group Performance, „The Journal of Abnormal and Social Psychology" 1951, nr 46.

Lewin K., Action Research and Minority Problems, [w:] Resolving Social Conflicts, red. G.W. Lewin, New York 1946.

Lincoln N.D., Travers Ch., Ackers P., Wilkinson A., The Meaning of Empowerment, the Interdisciplinary Etymology of a New Management Concept, „International Journal of Management Reviews" 2002, vol. 4, nr 3.

Manz Ch., Sims Jr. H., Leading Workers to Lead Themselves: The External Leadership of Self-Managing Work Teams, „Administrative Science Quarterly” 1987, vol. 32.

McClelland D.C., Achievement Motive, New York 1953.

McClelland D.C., The Achieving Society, Princeton NJ 1961.

Miyashiro M.R., Empathy Factor. Your Competitive Advantage for Personal, Team, and Business Success, Encinitas, CA 2011.

Penrose E.T., Growth of the Firm and Networking. W. Warner, ed. International Encyclopedia of Business and Management, London 1996.

Penrose E.T., The Theory of the Growth of the Firm, New York 1959.

Pfeffer J., Salancik G.R., The External Control of Organizations: A Resource Dependence Perspective, New York 1978.

Rosenberg M.B., Porozumienie bez przemocy: o języku życia, przeł. M. Kłobukowski, Warszawa 2017.

Schein E.H., Organisational Culture. „American Psychologist” 1990, vol. 43.

Tapscott D., Williams A., Makrowikinomia. Reset świata i biznesu, przeł. D. Bakalarz, Warszawa 2011.

Trzcionka M., Turkusowa Organizacja. Żywy organizm, [w:] Wybrane aspekty przemian gospodarczych w Polsce, red. M. Geise, J. Oczki, D. Piotrowski, Bydgoszcz 2018.

Wade J., Changes of Mind: A Holonomic Theory of the Evolution of Consciousness, New York 1996.

Wilber K., Eksplozja świadomości, przeł. K. Przechrzta, E. Kluz, Kraków 1997.

Wilber K., Niepodzielone. Wschodnie i zachodnie teorie rozwoju osobowości, przeł. T. Bieroń, Poznań 2014.

Wilber K., Psychologia integralna. Świadomość, duch, psychologia, terapia, przeł. H. Smagacz, Warszawa 2000.

Wilber K., The Atman Project: A Transpersonal View of Human Development, Wheaton IL 1996.

Wilkinson A., Empowerment Theory and Practice, „Personnel Review” 1998, vol. 27, nr 10. 
Marta KUŁAGA - magister filologii polskiej UJ. Przedsiębiorca, od 2000 roku prowadzi własną działalność gospodarczą „Przedszkole i żłobek Krasnal”, a od 2016 roku współtworzy turkusową organizację Leance. Trener Porozumienia bez Przemocy certyfikowana przez Centre for Nonviolent Communication (http://www.cnvc.org/), coach (2013-2014 Szkoła Profesjonalnego Coachingu, 2015 Coaching oparty na Potrzebach), absolwentka Szkoły Trenerów komunikacji opartej na empatii (2010-2013), mediatorka (2016-2017 Kurs mediacji NVC Yorama Mozensona).

dr Magdalena TRZCIONKA - adiunkt w Katedrze Polityki Zagranicznej i Stosunków Międzynarodowych INPiSM UJ. Jej zainteresowania orbitują wokół tematyki ekonomii opartej na wartościach oraz demokracji ekonomicznej. W tym kontekście analizuje obecnie działalność samozarządzających się organizacji (turkusowe organizacje), w tym stosowanych coraz częściej w praktyce gospodarczej nowatorskich technologii zarządzania i metod komunikacji (m.in. holakracja, agile oraz Porozumienie bez przemocy (NVC - nonviolent communictation)). Certyfikowany praktyk design thinking, action learning oraz dragon dreaming. 